\title{
Socio-Demographic Characteristics and Patterns of Substance Use Disorder in Oman
}

\section{A retrospective study of the National Registry Surveillance Programme between 2004 and 2018}

Mahmood Z. Al Abri, ${ }^{1}$ Mohamed A.H. Farag, ${ }^{2}$ Asaad S. Al Mosawi, ${ }^{3}$ "Salah T. Al Awaidy ${ }^{4}$

$$
\begin{aligned}
& \text { الخصائص الإجتماعية والديموغرافية وأنماط استخدام المواد المخدرة في عمان } \\
& \text { دراسة بأثر رجعي لبرنامج مراقبة السجل الوطني بين عامي } 2004 \text { و2018 }
\end{aligned}
$$

$$
\text { محمود زاهر العبري، محمد أمين فرج، أسعد سعيد الموسوي، صلاح ثابت العويدي }
$$

ABSTRACT: Objectives: Substance use disorder is a global challenge. Therefore, this study aimed to provide an updated view of socio-demographic characteristics and patterns of substance use in Oman. Methods: This retrospective descriptive study was conducted between 2004 and 2018. Data were retrieved from Oman's National Drug Addict Registry. The data collected included the socio-demographic characteristics of registered cases, the proportion of various psychoactive substances' consumption and their routes of administration, the associated sociodemographic determinants as well as comorbid conditions. Results: A total of 6,453 cases were registered during the study's timeframe. The majority of which were Omani (97.9\%), male (98.7\%), single (57.9\%), unemployed (50.2\%), had an education level below university (81.0\%) and were adolescents and young adults (77.0\%). Opiates were the most common substance used (66.6\%) and more than half of the sample were polydrug users (51.0\%). Injecting-drug users constituted $53.4 \%$ of the total registered cases. The proportion of people with hepatitis virus $\mathrm{C}$, hepatits virus $\mathrm{B}$ and HIV among the registered cases were $46.9 \%, 5.1 \%$ and 3.7\%, respectively. Conclusion: The findings are in favour of rapidly escalating the introduction of a substance use preventive programme at all school levels as well as making opioid substitution therapy and other harm reduction programmes available in Oman.

Keywords: Substance Use Disorders; Intravenous Drug Abuse; Opioid-Related Disorders; Comorbidity; Oman.

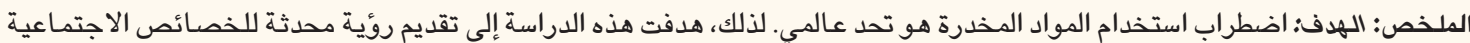

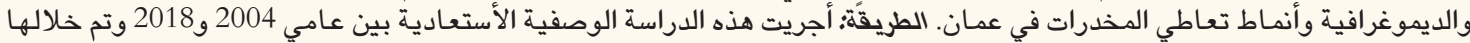

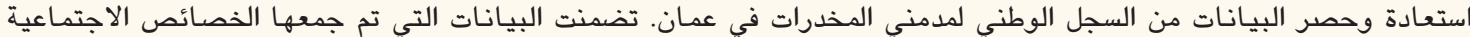

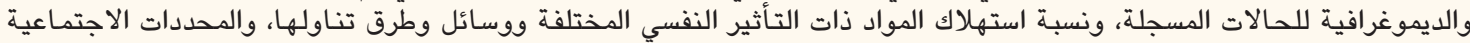

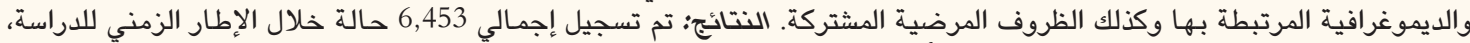

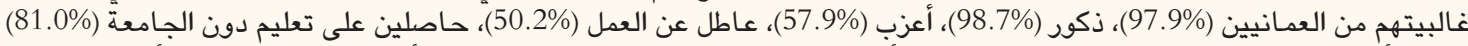

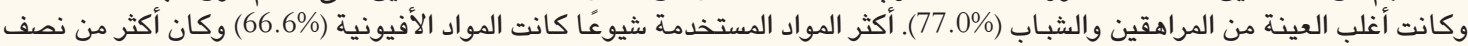

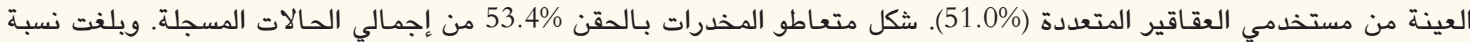

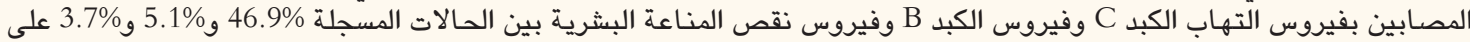

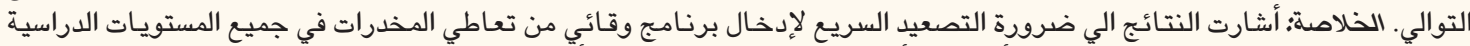

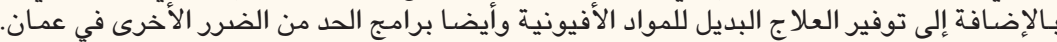

الكلمات المفتاحية؛ اضطرابات استخدام المخدرات؛ تعاطي المخدرات عن طريق الوريد؛ الاضطرابات المرتبطة بالمواد الأفيونية؛ الاعتلالات المصاحبة؛ عمان.

\section{AdVANCES IN KNOWLEDGE}

There is a high proportion of drug abuse in Oman primarily among young males.

The main illicit drugs consumed were opiates, cannabis and sedatives. The most typical combination was the polydrug use of opiates and cannabis, while injecting-drug users constituted over half of the total registered cases.

Associated comorbidities were found to be high and included hepatitis B and C virus HIV.

To the best of the authors' knowledge, this is the first comprehensive study describing patterns of substance use and the sociodemographic characteristics and comorbid conditions of drug users in Oman.

\section{Application to Patient Care}

This work could lead to activating preventive programmes at all school levels and introducing opioid substitution therapy and harm reduction plans. 
$\mathrm{S}$ UBSTANCE USE DISORDER (SUD) REMAINS A worldwide challenge despite efforts of public health authorities. ${ }^{1}$ Overwhelming evidence points to growing trends around substance use. ${ }^{1}$ Moreover, new illicit drugs are being manufactured and becoming available on the market. ${ }^{2}$ The United Nations Office on Drugs and Crime estimated that 275 million people (i.e. $5.6 \%$ of people between the ages of 15 and 64 years) used illicit drugs at least once in $2016 .{ }^{3}$ Only $35.0 \%$ of people suffering from SUD, however, received treatment in the same year. ${ }^{3}$

It has been estimated that around 31 million people worldwide who use drugs suffer from SUD, and 10.6 million of this total are injecting-drug users (IDUs). ${ }^{3}$ In 2015, the number of deaths due to druguse-related illnesses totalled 450,000 people. ${ }^{3}$ IDUs are notoriously vulnerable to blood-borne infections such as hepatitis $C$ virus ( $\mathrm{HCV}$ ), HIV and hepatitis $B$ virus (HBV). ${ }^{3}$ The proportion of HIV among IDUs was estimated at $11.8 \%$ (1.3 million) in 2016; out of this total, $82.4 \%$ were coinfected with $\mathrm{HCV}^{4}$

The concurrent or sequential use of more than one drug or type of drug is considered polydrug abuse. ${ }^{5}$ Health risks associated with polydrug use depend on the pharmacological properties and amounts of illicit drugs taken. Additionally, polydrug users have several distinctive psychosocial characteristics and environmental factors. Understanding the association of psychosocial factors with polydrug use is crucial in therapeutic interventions. ${ }^{6}$

The initiation and continuation of substance use appear to be influenced by the social environment. For example, sociology, psychology, anthropology and epidemiology are fields that have addressed the drug dependence phenomenon and evidence from these fields suggests that the aetiology of drug use is multifactorial. ${ }^{7}$ Genetic, psychological and social factors are considered determinants of drug abuse. ${ }^{8}$ Studies have also shown that socioeconomic and demographic factors such as inadequate education, poverty, homelessness and depression are associated with IDU in the developed world. ${ }^{7}$ Empirical evidence also suggests an inverse association between socioeconomic status and adult drug abuse. ${ }^{9}$

There is evidence that primary prevention activities that focus on improving the socioeconomic conditions of drug users would help change injection behaviours to a non-injecting mode of drug use or even prevent further drug use. ${ }^{10}$ Therefore, information about socio-demographic characteristics can be practical in setting preventive strategies. ${ }^{11}$

Oman is located in the southeastern corner of the Arabian Peninsula and is divided into 11 administrative governorates or provinces. These govern- orates are further subdivided into 61 wilayats, each with a governing centre. The population is concentrated in major urban centres which are largely the governorates' capitals, with relatively few people scattered across wilayats outside of the capitals. Oman's total population was estimated to be approxiamtely 4.6 million in mid-2017. ${ }^{12}$

Oman's geography is characterised by its extended coastline and is proximity to drug-producing countries. Its territory, therefore, is a transit point for drug trafficking in consuming countries and, consequently, illegal drugs leak into Oman. ${ }^{3}$

In response to the escalating global problem of illicit drug use, Oman's government established the National Committee for Narcotics and Psychoactive Substances (NCNP) in 2000 by a Royal decree issued in 1999. In 2004, the NCNP established the National Registry of Addiction (NRA), which consists of a surveillance programme for alcohol and illicit drug use. It obtains data from health institutes, police and offices of public persecution. A special notification form for reporting cases of drug users who seek medical care was issued and distributed to the designated healthcare settings in all governorates. The notification form includes the sociodemographic characteristics of drug users, substance-related variables and associated physical and medical comorbidities.

To the authors' best knowledge, there is a paucity of literature describing the sociodemography of drug users in Oman. ${ }^{13,14}$ Therefore, this study aimed to describe the sociodemographic characteristics of cases registered in the NRA, the proportion of various psychoactive substances' consumption among registered cases, their routes of administration and their associated comorbidities.

\section{Methods}

This retrospective descriptive study used data collected between 2004 and 2018 from designated healthcare settings and secondary data collected from annual reports. Data were collected within healthcare settings, sent to the NRA and used to describe the socio-demographic characteristics of individuals who had sought medical care in those settings for drug use. Secondary data were extracted from the 2017 and 2018 Annual Reports for Narcotics and Psychotropic Substances. ${ }^{15-17}$ These annual reports included previously collected data from 2004 and 2018 from designated healthcare settings; these data were also sent to the NRA and describe the socio-demographic characteristics of drug users among individuals who sought medical care. The specific information typically collected included baseline demographic 
characteristics (age, gender, marital status, residency, employment status, education level and nationality); types of illicit drugs used and routes of their administration (injection versus non-injection); and medical co-morbidities including HCV, HBV and HIV.

The percentage distribution of cases was calculated according to illicit drug(s) consumed, the distribution of cases, according to the specific psychoactive substance used and trends of substance intake among registered cases. Data were analysed using Statistical Package for the Social Sciences (SPSS), Version 22 (IBM, Corp., Armonk, New York, USA). Numbers and comparable percentages were used to describe categorical data. Mean \pm standard deviation was used to describe continuous data. The statistical association between two dichotomous nominal variables was carried out using cross-tabulation and chi-square test for significance. The association between one ordinal and one nominal variable was carried out using linearby-linear association (chi-square test for trends). A $P$ value of $\leq 0.05$ was considered statistically significant.

The data collected did not include human subjects in terms of interviews or the use of patients' personal data files. The researchers used extant data extracted from the official national register of drug addiction, which had already been published in an official domain. ${ }^{15-17}$ This study was approved by the internal Institutional Review board and adheres to the Declaration of Helsinki.

\section{Results}

A total of 6,453 cases were reported to NRA between 2004 and 2018. Of this total, 6,370 (98.7\%) were male and $83(1.3 \%)$ were female $(P<0.05)$. The mean age at diagnosis was $32 \pm 9$ years (range: $12-78$ years). Of the total cases, 4,946 (76.6\%) were between 21 and 40 years old. Most cases had the marital status of single (57.9\%). In terms of educational level, 5,319 $(81.0 \%)$ had between a primary and secondary school education; only 569 (8.8\%) pursued a higher education (i.e. university). A total of 3,237 (50.2\%) cases reported being unemployed while 2,611 (40.5\%) were employed and $170(2.6 \%)$ were students at the time of diagnosis while 271 (4.2\%) were retired. There were 6,317 cases with Omani nationality (97.9\%) and 3,945 (62.0\%) were from Muscat Governorate; the remaining sample were from governorates outside Muscat [Table 1].

Opiates were consumed by 4,300 (66.6\%) of the registered cases followed by alcohol ( $\mathrm{n}=4,256$; $66.0 \%)$, cannabis ( $\mathrm{n}=3,664 ; 56.8 \%)$ and sedatives ( $\mathrm{n}=2,337 ; 36.2 \%$ ); stimulants, volatile solvents and hallucinogenics were consumed by 344 (5.3\%), 211 (3.3\%) and $146(2.3 \%)$, respectively [Figure 1]. The
Table 1: Sociodemographic characteristics of registered cases of drug use in Oman from 2004-2018 $(\mathrm{N}=6,453)$

\begin{tabular}{|c|c|}
\hline Variables & n (\%) \\
\hline \multicolumn{2}{|l|}{ Age in years } \\
\hline$\leq 20$ & $455(7.1)$ \\
\hline $21-30$ & $2,876(44.6)$ \\
\hline $31-40$ & $2,070(32.1)$ \\
\hline $41-50$ & $781(12.1)$ \\
\hline $51-60$ & $225(3.5)$ \\
\hline$>60$ & $46(0.7)$ \\
\hline \multicolumn{2}{|l|}{ Gender } \\
\hline Male & $6,370(98.7)$ \\
\hline Female & $83(1.3)$ \\
\hline \multicolumn{2}{|l|}{ Marital status } \\
\hline Single & $3,739(57.9)$ \\
\hline Married & $2,310(35.8)$ \\
\hline Divorced & $378(5.9)$ \\
\hline Widow & $26(0.4)$ \\
\hline \multicolumn{2}{|l|}{ Employment status } \\
\hline Employed & $2,611(40.5)$ \\
\hline Unemployed & $3,237(50.2)$ \\
\hline Retired & $271(4.2)$ \\
\hline Student & $170(2.6)$ \\
\hline Undetermined & $164(2.5)$ \\
\hline \multicolumn{2}{|c|}{ Highest educational level } \\
\hline Illiterate* & $209(3.2)$ \\
\hline Can read and write* & $323(5.0)$ \\
\hline Primary school & $1,517(23.5)$ \\
\hline Intermediate school & $1,685(26.1)$ \\
\hline Secondary school & $2,017(31.3)$ \\
\hline University & $569(8.8)$ \\
\hline Undetermined & $133(2.1)$ \\
\hline \multicolumn{2}{|l|}{ Nationality } \\
\hline Omani & 6,317 (97.9) \\
\hline Non-Omani & $136(2.1)$ \\
\hline \multicolumn{2}{|c|}{ Governorate of residence } \\
\hline Muscat & $3,945(61.8)$ \\
\hline North Batinah & $945(14.8)$ \\
\hline Dakhliyah & $296(4.6)$ \\
\hline South Batinah & $294(4.6)$ \\
\hline Other & $973(14.2)$ \\
\hline
\end{tabular}




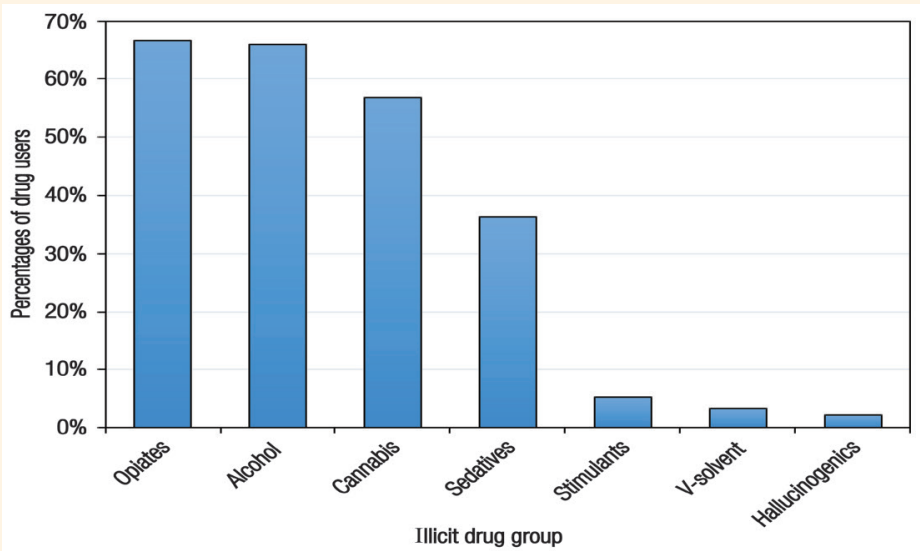

Figure 1: Percentage distribution of cases according to the consumed illicit drug groups from 2014 to 2018 in Oman ${ }^{14-16}$

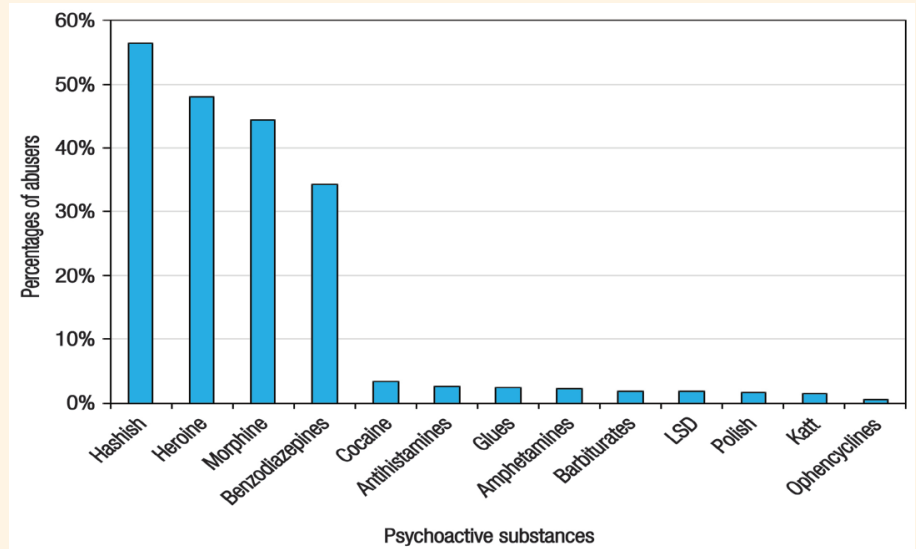

Figure 2: Percentage distribution of cases according to the individual psychoactive substance used from 2014 to 2018 in $\mathrm{Oman}^{14-16}$

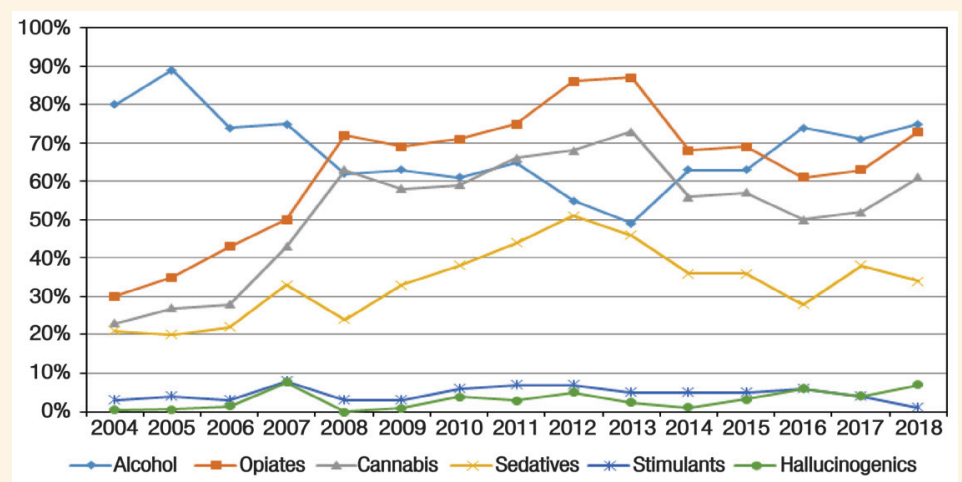

Figure 3: Temporal trends of substance intake among registered cases from 2004 to 2018 in Oman ${ }^{14-16}$

four most consumed substances were hashish (56.4\%), heroin (48\%), morphine (44.0\%) and benzodiazepines (34.0\%), while other substances were used at a rate of $0.4-3 \%$ [Figure 2]. It is worth noting that $82 \%$ of morphine abusers were IDUs. The four particular psychoactive substances consumed by males versus females were, in order of most frequently to least frequently consumed: opiates (66.0\% versus $79.0 \%)$, alcohol (66.0\% versus 51.0\%), cannabis (57.0\% versus $43.0 \%$ ) and sedatives (36.0\% versus 37.0\%). However, more females versus males were using stimulants (10.0\% versus $5.0 \%)$.

Of the registered cases, $51.0 \%$ consumed more than one illicit drug and almost 33.0\% used three and $20.0 \%$ used four drugs. The most common combinations were opiates and cannabis, which was consumed by 
$51.0 \%$ of the total registered cases followed by alcohol and opiates (37.0\%); alcohol and cannabis (36.0\%); opiates and sedatives (32.0\%); and alcohol, opiates and cannabis $(31.0 \%)$. It is worth noting that alcohol and opiates were used as monodrugs in $22.0 \%(n=1,466)$ and $8.0 \%(\mathrm{n}=539)$ of cases, respectively.

Alcohol was consumed by almost $90.0 \%$ of the cases in 2005 , then gradually decreased to $49.0 \%$ in 2013 and then increased to $75.0 \%$ in 2018. There was a steady increase in opiate consumption from $30.0 \%$ in 2004 to $87.0 \%$ in 2013 . Opiate consumption, then gradually decreased to $61.0 \%$ in 2016 and then increased in 2017 and 2018. Cannabis consumption followed similar trends as opiates but to a lesser extent. Sedative consumption demonstrated a steady increase from 21\% in 2004 to $51.0 \%$ in 2012 followed by a gradual decrease to $34.0 \%$ in 2018 . On the other hand, stimulant abuse was uniform and did not reach more than $8.0 \%$ of the total consumption in any given year. With regard to hallucinogens, their annual consumption ranged from $0.0 \%$ in 2004 to $7.0 \%$ in 2018 [Figure 3].

The consumption of all psychoactive substances varied significantly with age groups, educational level, employment status and marital status $(P<0.05$ each) except for hallucinogens, which indicated no difference in relation to marital status $(P=0.13)$. On the other hand, there were no significant gender differences for any substance except alcohol $(P<0.05)$. There were significant differences in the consumption of opiates, stimulants, and hallucinogens between Omani and non-Omani users $(P<0.05$ each) but no differences in alcohol, cannabis, sedatives or volatile solvents $(P>0.05$ each $)$.

IDUs constituted $53.0 \%(\mathrm{n}=3,418)$ of the total registered cases, growing from $23.0 \%$ of cases registered in 2004 to $45.0 \%$ in 2018 and peaking at $71.0 \%$ in 2013 . The routes of administration (injecting vs. non-injecting) were dependent on age groups, employment status, educational level and marital status $(P<0.05$ each $)$ but were not dependent on gender $(P=0.23)$.

The most prevalent blood-borne infection among cases was HCV (46.9\% of those tested were infected). The proportion of HBV and HIV was 5.1\% and 3.7\%, respectively. However, 50.6\%, 49.6\% and $47.9 \%$ were not tested for HCV, HBV or HIV, respectively. Out of the total tested IDUs, $67.4 \%$ were positive for HCV. They were almost 12 times more likely to be infected with HCV than non-IDUs. Moreover, of people who indicated injecting drugs for $\geq 5$ years, 689 individuals were tested for $\mathrm{HCV}$ and 520 (75.5\%) were found to be infected.

\section{Discussion}

Drug abusers reported to the NRA in Oman constitute a young community with marked male predominancemore than two-thirds were between 21 and 40 years. Considering that the ages reported to NRA represent the ages at diagnosis, the age at which people in Oman initiate drug use must therefore be much younger. This age distribution and male predominance are comparable to other published studies in the region.,17 This relatively young community of abusers necessitates designing prevention programmes to intervene as early as preschool to address risk factors for drug abuse such as aggressive behaviour, poor social skills and academic difficulties. ${ }^{18}$

Fortunately, a special international school preventive programme named "Unplugged" was launched in Oman in 2018 as a pilot study in selective schools and has been generalised to all schools since 2019/2020. Regrettably, some surveillance notifications were lacking information related to age at the initiation of substance use.

The social and biological predisposing factors for initiation and continuation of substance use vary considerably between men and women. ${ }^{12}$ One important observation in this study was the extensive under-reporting of female illicit drug users. Women constituted only $1.3 \%$ of the total registered cases, which may not reflect the true proportion of substance use among women. For comparison, in the United States males were reported to be 1.9 times more likely to have had drug dependence than females. ${ }^{19}$ Moreover, women constitute $20-30 \%$ of drug users under treatment at the global level and are more likely than men to be infected with HIV. ${ }^{3}$ Possible reasons for Omani women's underreporting drug use may be fear of social stigma, losing child custody, facing legal consequences or a lack of special services to address drug use in women.

Almost $81 \%$ of drug users had only completed primary or secondary school levels. This finding is comparable with international studies, which address the negative impact of drug use on school performance. $^{20,21}$ Additionally, students who are potentially under the influence of such substances are not ready to learn and are at risk of long-term impairment of cognitive ability and memory as well as lack of motivation and reduced school attendance. ${ }^{20,21}$

In the current study, more than half of the drug users were unemployed and single. These findings are comparable to a study where unemployment and being unmarried were found to be among social 
determinants of illicit drug use in United Arab Emirates. ${ }^{22,23}$

Another important finding was the very low percentage of non-Omani drug users (2.1\%). This finding could be explained by expatriates' reluctance to seek medical care due to the potential fear of discrimination, legal liability, imprisonment or repatriation. Other barriers were lack of access to governmental medical care and difficulties to cover the cost of private medical care. ${ }^{24}$

Although the findings from this study are limited to registered cases in the NRA, it is important to estimate the proportion and pattern of drug use among them so that decision-makers and healthcare providers can manage medical stocks and healthcare services accordingly. ${ }^{24}$

Although data from NRA likely do not reflect the true proportion of drug abuse in the country, they provide an indication of the substances that are used most. Opiates were found to be the most commonly used substances in this study and heroin was the most commonly used drug among the opiates (48.0\%). Similar findings were found in other Gulf Cooperation Council countries. ${ }^{23,25}$ Because heroin is highly addictive and leads to global life deterioration, harm minimisation and substitution treatment programmes are essential to be considered at this stage.

This study showed that $53.4 \%$ of cases were IDUs. This group tends to start using drugs at younger ages and consequently reports a more extended duration of drug use. ${ }^{26}$ The current findings were comparable to those of other studies, which indicated that IDUs have lower education levels compared to non-IDUs. ${ }^{26}$ These findings can be explained by the high-risk behaviour of younger age groups associated with lack of awareness or insight to the consequences of IDUs.

IDUs experience a double burden-they suffer complications from drug use and are also vulnerable to blood-borne infectious diseases. Reflective of this burden is the finding that the proportion of $\mathrm{HCV}$ among IDUs is 25 times higher than among the general population. ${ }^{27}$ The findings of the current study showed that HCV was the most prevalent blood-borne infection among registered drug users in general (46.9\%) and IDUs in particular (67.4\%). This trend in this study appears to be echoed in other Arab countries. ${ }^{28}$

The number of years a person has been an IDU is known to correlate with the presence of $\mathrm{HCV}$ infection. ${ }^{29}$ The current study's data show that $75.5 \%$ of IDUs who had indicated using for $\geq 5$ years were infected with HCV. This percentage is $10 \%$ higher than the worldwide midpoint prevalence of $\mathrm{HCV}$ among IDUs $(67.0 \%) .^{30}$
The proportion of HIV among the registered cases in the current study was $3.7 \%$. This finding was similar to the proportion discovered in a recent study conducted in Oman. ${ }^{13}$ Among the risk factors that increase the probability of blood-borne infections among IDUs is sharing needles. ${ }^{31}$ In 2010, almost two million years of life were lost worldwide in conjunction with unsafe injecting drug use and through premature death as a consequence of HIV infection; a further half million years of life were lost due to $\mathrm{HCV}^{32}$ Unfortunately, no data about needle sharing habits were included in the national registry data used in the current study.

The relative youth of the IDUs in addition to the sizeable percentage of morphine users and the low proportion of stimulant use among this group points to the importance of seriously considering introducing opiate substitution therapy. These therapies might include methadone maintenance therapy (MMT) and other harm reduction programmes such as a nationwide needle/syringe exchange programme and HIV voluntary counselling and testing (VCT) to reduce the negative consequences of drug abuse. ${ }^{33}$ The Omani Ministry of Health established VCT services in four primary healthcare centres in 2015 but MMT and needle/syringe exchange programmes have not been implemented.

This study's finding of a relatively high number of cases using more than one illicit drug is alarming. Alcohol was found to be used alone by $22.7 \%$ of cases and in combination with opiates and cannabis in $37.0 \%$ and $36.0 \%$ of cases, respectively. In comparison, the US Department of Health and Human Services found that $65 \%$ of admissions under 20 years reported polydrug abuse compared to $41 \%$ of admissions over $45 .{ }^{34}$ Users' perceptions of a drug's availability and cost have been found to facilitate polydrug use behaviours. ${ }^{35}$ Because $51.0 \%$ of cases in this study are polydrug users, an overdose prevention programme and/or substitution and harm minimisation programmes are recommended.

This study has some limitations. The data considered were limited to NRA registers, which depends on the notification reports of governmental health institutes. Expatriate residents' data, therefore, were not included in this study. Also, almost half of the reported cases were not tested for $\mathrm{HCV}, \mathrm{HBV}$ and $\mathrm{HIV}$, which adversely affects the generalisability of the results. Other important limitations are the lack of information about needle sharing and mortality rate among drug users. Both of these data points should be added to the notification form in the future. 


\section{Conclusion}

Drug users in Oman comprise a young community, with more than $80 \%$ having achieved below a university level of education. The main illicit drugs used were opiates, cannabis and sedatives. The most typical combination was the simultaneous use of opiates and cannabis. The young age of IDUs, the sizeable percentage of morphine abusers and the high proportion of medical comorbidity suggests an urgent need for escalating the introduction of a substance abuse prevention programme at schools. Also potentially beneficial would be the introduction of opiate substitution therapy and other harm reduction programmes. A further recommendation would be to expand mandates to require private health sectors to promptly notify the NRA of cases and screen known drug users for blood-borne infections. Additionally, a national survey is recommended to estimate the proportion and social determinants of SUD data in Oman.

\section{DATA AVAILABILITY STATEMENT}

The datasets used and/or analysed during the current study are available from Oman's Office or Committee for Narcotics \& Psychotropic Substances upon reasonable request.

\section{CONFLICT OF INTEREST}

The authors declare no conflict of interest.

\section{FUNDING}

No funding was received for this study.

\section{References}

1. Juyal R, Bansal R, Kishore S, Negi KS. Socio-demographic characteristics of substance abusers among intercollege students in a district of Uttarakhand. JK Sci 2008; 10:116-19.

2. Spooner C, Hetherington K. Social determinants of drug use. From: https://ndarc.med.unsw.edu.au/sites/default/files/ ndarc/resources/TR.228.pdf Accessed: Apr 2020.

3. United Nation Office on Drugs and Crime. World Drug Report 2018. From: www.unodc.org/wdr2018 Accessed: Apr 2020

4. Platt L, Easterbrook P, Gower E, McDonald B, Sabin K, McGowan C, et al. Prevalence and burden of HCV co-infection in people living with HIV: A global systematic review and meta-analysis. Lancet Infect Dis 2016; 16:797-808. https://doi. org/10.1016/s1473-3099(15)00485-5.

5. World Health Organization. Lexicon of alcohol and drug terms. From: https://apps.who.int/iris/handle/10665/39461 Accessed: Apr 2020.

6. European Monitoring Centre for Drugs and Drug Addiction. Annual report on the state of the drugs problem in the European Union and Norway. From: https://www.emcdda. europa.eu/system/files/publications/923/ar2004-en1_69524. pdf. Accessed: Apr 2020.
7. Yoshikawa H, Aber JL, Beardslee WR. The effects of poverty on the mental, emotional, and behavioral health of children and youth: Implications for prevention. Am Psychol 2012; 67:272-84. https://doi.org/10.1037/a0028015.

8. Kalaydjian A, Swendsen J, Chiu WT, Dierker L, Degenhardt L, Glantz M, et al. Sociodemographic predictors of transitions across stages of alcohol use, disorders, and remission in the National Comorbidity Survey Replication. Compr Psychiatry 2009;50:299-306.https://doi.org/10.1016/j.comppsych.2008.09.012.

9. Pentz MA. Costs, benefits, and cost-effectiveness of comprehensive drug abuse prevention. In: Bukoski WJ, Evans RI, Eds. Cost-Benefit/Cost-Effectiveness Research of Drug Abuse Prevention: Implications for Programming and Policy. Washington, DC, USA: U.S. Government Printing Office, 1998. Pp. 111-129. https://doi.org/10.1037/e495512006-007.

10. Atilola $\mathrm{O}$, Ayinde $\mathrm{O}$, Adeitan $\mathrm{O}$. Beyond prevalence and pattern: Problematic extent of alcohol and substance use among adolescents in Ibadan South-west Nigeria. Afr Health Sci 2013; 13:777-84. https://doi.org/10.4314/ahs.v13i3.37.

11. National Center for Statistics and Information. Statistical Yearbook 2018. From: www.ncsi.gov.om/Elibrary/Pages/Librar yContentDetails.aspx? ItemID=GxJuqSZUD0v4K7T\% 2FPJp13A\%3D\%3D Accessed: Apr 2020.

12. Jaffer YA, Afifi M, Al Ajmi F, Alouhaishi K. Knowledge, attitudes and practices of secondary-school pupils in Oman: Health-compromising behaviours. E Mediterr Health J 2006; 12:35-49.

13. Al Wahaibi N, Al Lawati A, Al Ruqeishy F, Al Khatri A, Al-Farsi Y, Juma TMA, et al. The characteristics and patterns of utilization of healthcare services among Omanis with substance use disorders attending therapy for cessation. PLoS One 2019; 14:e0210532. https://doi.org/10.1371/journal.pone.0210532.

14. Ministry of Health Oman. National Committee for Narcotics and Psychoactive Substance. Annual Report for Narcotics and Psychotropic Substance 2017.

15. Ministry of Health Oman. National Committee for Narcotics and Psychoactive Substance. [Annual Report for Narcotics and Psychotropic Substance 2017]. Arabic version.

16. Ministry of Health Oman. National Committee for Narcotics and Psychoactive Substance. Annual Report for Narcotics and Psychotropic Substance 2018.

17. Glick P, Khammash U, Shaheen M, Brown R, Goutam P, Karam R, et al. Perceived peer norms, health risk behaviors, and clustering of risk behaviors among Palestinian youth. PloS One 2018; 13:e0198435. https://doi.org/10.1371/journal. pone. 0198435 .

18. Webster-Stratton C, Reid MJ, Hammond M. Preventing conduct problems, promoting social competence: A parent and teacher training partnership in Head Start. J Clin Child Psychol 2001; 30:282-302. https://doi.org/10.1207/S15374424JCCP3003_2.

19. Compton WM, Thomas YF, Stinson FS, Grant BF. Prevalence, correlates, disability, and comorbidity of DSM-IV drug abuse and dependence in the United States: Results from the National Epidemiologic Survey on Alcohol and Related Conditions. Arch Gen Psychiatry 2007; 64:566-76. https://doi.org/10.1001/ archpsyc.64.5.566.

20. Sheikh KA, El-Setouhy M, Yagoub U, Alsanosy R, Ahmed Z. Khat chewing and health related quality of life: Cross-sectional study in Jazan region, Kingdom of Saudi Arabia. Health Qual Life Outcomes 2014; 12:44. https://doi.org/10.1186/1477-7525-12-44.

21. Blum K, Schoenthaler SJ, Oscar-Berman M, Giordano J, Madigan MA, Braverman ER, et al. Drug abuse relapse rates linked to level of education: Can we repair hypodopaminergic-induced cognitive decline with nutrient therapy? Phys Sportsmed 2014; 42:130-45. https://doi.org/10.3810/psm.2014.05.2065. 
22. Elkashef A, Zoubeidi T, Thomas RA, Al Hashmi H, Lee AJ, Aw TC, et al. A profile of patients with substance use disorders and treatment outcomes: A 10-year retrospective study from the National Rehabilitation Center. Int J Prev Treat Subst Use Disord 2013; 1:62-75. https://doi.org/10.4038/ijptsud.v1i1.5912.

23. Alblooshi H, Hulse GK, El Kashef A, Al Hashmi H, Shawky M, Al Ghaferi $\mathrm{H}$, et al. The pattern of substance use disorder in the United Arab Emirates in 2015: Results of a National Rehabilitation Center cohort study. Subst Abuse Treat Prev Policy 2016; 11:19. https://doi.org/10.1186/s13011-016-0062-5.

24. Johnston LD, O'Malley PM, Bachman JG, Schulenberg JE. Monitoring the future national survey results on drug use, 1975-2009. From: https://files.eric.ed.gov/fulltext/ED514370. pdf Accessed: Apr 2020.

25. Alshomrani AT, Khoja AT, Alseraihah SF, Mahmoud MA. Drug use patterns and demographic correlations of residents of Saudi therapeutic communities for addiction. J Taibah Univ Med Sci 2017; 12:304-12. https://doi.org/10.1016/j.jtumed.2017.02.006.

26. Noroozi M, Nedjat S, Golestan B, Majdzadeh R. What are differences between non-injecting and injecting drug addicts? Int J Prev Med 2012; 3:414-19.

27. Global Burden of Hepatitis C Working Group. Global burden of disease (GBD) for hepatitis C. J Clin Pharmacol 2004; 44:20-9. https://doi.org/10.1177/0091270003258669.

28. Daw MA, Dau AA. Hepatitis C virus in Arab world: A state of concern. ScientificWorldJournal 2012; 2012:719494. https://doi.org/10.1100/2012/719494.

29. Centers for Disease Control and Prevention. Recommendations for prevention and control of hepatitis $\mathrm{C}$ virus (HCV) infection and HCV-related chronic disease. From: https://www.cdc.gov/ mmwr/preview/mmwrhtml/00055154.htm Accessed: Apr 2020.
30. Nelson PK, Mathers BM, Cowie B, Hagan H, Des Jarlais D, Horyniak D, et al. Global epidemiology of hepatitis B and hepatitis $\mathrm{C}$ in people who inject drugs: Results of systematic reviews. Lancet 2011; 378:571-83. https://doi.org/10.1016/ S0140-6736(11)61097-0.

31. Mehta SH, Astemborski J, Kirk GD, Strathdee SA, Nelson KE, Vlahov D, et al. Changes in blood-borne infection risk among injection drug users. J Infect Dis 2011; 203:587-94. https://doi. org/10.1093/infdis/jiq112.

32. Degenhardt L, Whiteford HA, Ferrari AJ, Baxter AJ, Charlson FJ, Hall WD, et al. Global burden of disease attributable to illicit drug use and dependence: Findings from the Global Burden of Disease Study 2010. Lancet 2013; 382:1564-74. https://doi. org/10.1016/S0140-6736(13)61530-5.

33. Connock M, Juarez-Garcia A, Jowett S, Frew E, Liu Z, Taylor RJ, et al. Methadone and buprenorphine for the management of opioid dependence. A systematic review and economic evaluation. Health Technol Assess 2007; 11:1-171. https://doi. org/10.3310/hta11090.

34. U.S. Department of Health and Human Services. The DASIS Report: Polydrug Admissions-2002. From: www.samhsa.gov/ data/sites/default/files/TEDS2012N_Web.pdf. Accessed: Apr 2020

35. Bobashev G, Tebbe K, Peiper N, Hoffer L. Polydrug use among heroin users in Cleveland, OH. Drug Alcohol Depend 2018; 192:80-7. https://doi.org/10.1016/j.drugalcdep.2018.06.039. 